\title{
Milestone Sistem Perniagaan Karet di Rimbo Bujang Rentang Tahun 1980-2020
}

\author{
Sugeng Riyadi \\ UIN Prof. K. H. Saifuddin Zuhri Purwokerto, Indonesia \\ email: sugengriyadi@iainpurwokerto.ac.id
}

Manuscript History:

Received: 05-09-2021

Accepted: 12-10-2021

Published: 13-10-2021

\begin{abstract}
Processed rubber material (bokar) is a commodity that has been the mainstay of the Indonesian government. In order to realize the hegemony of production, the government organizes a transmigration program. This is at the same time to overcome the population problem on the island of Java. This qualitative type of research was carried out using the Bogdan and Taylor field approach using time series data. Patton's data analysis process, presented with manageable data. The data interpretation uses ideal types, path dependency and contingency strategies and Neuman's domain analysis. Research in Rimbo Bujang, in the 1980-2020 period, shows that the rubber trading system in the ex-transmigration sites of Jambi Province can be classified into three phases: first, trade between transmigrant farmers and the government. Second, farmers trade with cooperatives and middlemen. Third, farmers trade with middlemen using an auction pattern. Although the transmigration program in Rimbo Bujang was successful, it still left socio-economic problems, triggered by the trade system which tends to ignore Islamic economic principles. Findings in the field indicate that the absence of the state in plantation smallholder commerce contributes to the moral hazard of market participants. The change of plantation varieties from rubber to oil palm in the last decade does not rule out the possibility of repeating the previous cycle of rubber trading patterns.
\end{abstract}

Keywords: system; commerce; rubber; rimbo bujang

\begin{abstract}
Abstrak
Bahan olahan karet (bokar) merupakan komoditas yang pernah menjadi andalan pemerintah Indonesia. Guna merealisasikan hegemoni produksi, pemerintah menyelenggarakan program transmigrasi. Hal ini sekaligus untuk menanggulangi problem kependudukan di pulau Jawa. Penelitian berjenis kualitatif ini dilaksanakan dengan pendekatan lapangan Bogdan dan Taylor secara time series data. Proses analisa data Patton, disajikan dengan manageabledata. Adapun interpretasi data digunakan strategi ideal types, path dependencyand contingency maupun domain analysis Neuman. Riset di Rimbo Bujang, dalam rentang tahun 1980-2020 menunjukkan bahwa sistem perniagaan karet di eks-lokasi transmigrasi Propinsi Jambi ini dapat diklasifikasikan ke dalam tiga fase: pertama, perniagaan petani transmigran dengan pemerintah. Kedua, perniagaan petani dengan koperasi dan tengkulak. Ketiga, perniagaan petani dengan tengkulak menggunakan pola lelang. Meski program transmigrasi di Rimbo Bujang terbilang berhasil, namun masih menyisakan problem sosial
\end{abstract}


ekonomi, dipicu oleh sistem perniagaan yang cenderung mengabaikan prinsip-prinsip ekonomi Islam. Temuan di lapangan menyebutkan bahwa ketidakhadiran negara dalam perniagaan petani perkebunan berkontribusi menimbulkan moral hazzard dari para pelaku pasar. Pergantian varietas perkebunan dari karet menjadi kelapa sawit pada dasawarsa terakhir tidak menutup kemungkinan mengulang siklus pola perniagaan karet sebelumnya.

Kata Kunci: sistem; perniagaan; karet; rimbo bujang

\section{PENDAHULUAN}

Karet alam merupakan salah satu komoditi perkebunan yang strategis bagi Indonesia. Ditinjau dari luas areal dan poduksi, karet Indonesia didominasi oleh karet rakyat. Pada tahun 1990 perkebunan karet rakyat tercatat 476.859 hektar (84\%) dengan produksi 209.447 ton (76\%) (Lindayanti, 1993), sisanya merupakan perkebunan besar negara dan perkebunan besar swasta. Namun demikian perkebunan karet rakyat kondisinya belum kuat dan mantap antara lain: 61\% dari total areal karet merupakan tanaman tua menghasilkan, produktivitas rendah $673 \mathrm{~kg} / \mathrm{ha} /$ tahun karena menggunakan bahan tanaman tidak unggul dan minimnya pemeliharaan, serta sistem tata-niaga yang kurang menguntungkan bagi petani karet (Sunjaya, 1998). Dengan tidak produktifnya perkebunan karet untuk satu kapling (dua hektar) rata-rata hanya menghasilkan 10-15 Kg karet per hari/satu kali sadap, yang dulu ketika masih produktif bisa mencapai 50-70 Kg karet per hari/satu kali sadap. Curahan waktu kerja pun mengalami perubahan yang tidak produktif. Ketika perkebunan karet masih produktif, masyarakat bekerja untuk mengelolah kebun (menyadap pohon karet) empat sampai lima jam perhari, namun sekarang mereka membutuhkan waktu 5-7 jam untuk menyadap pohon karet seluas dua hektar (satu kapling) per-harinya (Syuhada \& Kuswanto, 2009). Sementara, menurut data series perkebunan pada tahun 2000 luas perkebunan karet di provinsi Jambi seluas 190.907 hektar (BPS, 2021) dan seluas 398.036 hektar pada tahun 2020 (Kementan RI, 2021).

Sementara, luas lahan yang diremajakan atas berbagai program pemerintah mencapai 18.854 hektar diantaranya 1.354 hektar (7,18\%) tahun 2006, 14.000 hektar $(74,25)$ pada tahun 2007 dan 3.500 hektar $(18,56)$ pada tahun 2008. Peremajaan terbesar terdapat di Kabupaten Bungodan Merangin, sedangkan terkecil di Kabupaten Kerinci, Tanjung Jabung Baratdan Tanjung Jabung Timur. Apabila lahan tanaman karet yang diremajakan initermasuk dalam luas 136.000 hektar yang perlu diremajakan seperti data yangdikeluarkan oleh Dinas Perkebunan Provinsi pada tahun 2005, maka dari luas ini, telah diremajakan sebesar 13,86\%, dengan sumber dana APBD Provinsi (Sihotang, 2009). Di sisi lain, salah satu upaya untuk meningkatkan perbaikan mutu bahan olah karet rakyat dan sistem pemasaran hasil, pemerintah melalui Surat Keputusan Menteri Pertanian Nomor I57/KptsfHK.050/2/I993 telah membentuk Proyek Pengembangan Unit Pengolahan Karet Rakyat (PPUPKR) yang tersebar di 6 provinsi yaitu Riau, Jambi, Sumatera Selatan, Kalimantan Barat, Kalimantan Tengah, dan Kalimantan Selatan. 
Diskursus pasar merupakan variabel fundamental dalam struktur problematika Perkebunan Inti Rakyat (PIR). Dan adalah suatu keniscayaan, bahwa fluktuasi harga serta mekanisme perniagaan menjadi indikator stimulasi simbiosis bagi daya produktivitas petani. Selain premis tersebut, mekanisme terbentuknya harga dan model pasar merupakan diskursus lainnya yang juga mengganggu kedaulatan kesejahteraan petani Perkebunan Inti Rakyat (PIR). Dalam perspektif kesejarahan, entitas petani Perkebunan Inti Rakyat (PIR) di Provinsi Jambi merupakan kaum transmigran yang semenjak tahun 1975 didatangkan dari pelbagai daerah di pulau Jawa. Program transmigrasi di Provinsi Jambi, khususnya di Kabupaten Tebo, merupakan proyek perluasan hutan produksi nasional yang difasilitasi pihak ketiga, yaitu Perseroan Terbatas Perkebunan (PTP) Nusantara VI.

Di Kecamatan Rimbo Bujang sendiri, pemetaan transmigran sebagai petani agronomis terstruktur ke dalam bentuk unit-unit pedesaan. Adapun model relasi kontrakkepemilikan lahan (kapling) yang dibangun antara petani transmigran dengan pihak PTP Nusantara VI identik dengan ijarah muntabiyabi al-tamlik. Sementara dalam relasi perniagaan produksi, yang dikembangkan oleh pihak PTP Nusantara VI terhadap petanilebih berupa jual-beli terikat (ba'y al-muqayyad). Mekanisme jual-beli ini tidak terlepas dari aspek pembiayaan administratif transmigrasi antara PTP Nusantara VI dengan pihak pemerintah. Dimana pada nilai lunas setoran produksi petaniyang tercatat Tempat Pengolahan Hasil (TPH), maka para petanitersebut akan memperoleh sertifikat hak milik kapling lahan sesuai pagu pembiayaan transmigrasi.

Berdasarkan premis dan diskursus di atas, narasi riset ini bermaksud melakukan tindakan pengungkapan, penawaran pemikiran konsep perdagangan dan pemberdayaan terhadap komunitas kelompok petani karet. Suatu hal yang belum pernah dilakukan sebelumnya. Di sini, terdapat beberapa alasan pemilihan subyek dampingan, yaitu komunitas petani karet di Desa Rimbo Mulyo sebagai salah satu desa di Kecamatan Rimbo Bujang Kabupaten Tebo Provinsi Jambi. Dalam hal ini adalah sebagaimana berikut ini: Pertama, permasalahan pertumbuhan kelompok petani. Kelompok petani yang akan menjadi mitra dampingan adalah obyek dengan jumlah komunitas kelompok petani terbanyak dalam satu desa se-kecamatan Rimbo Bujang. Namun demikian antara satu dengan lainnya, berbagai kelompok petani karet ini tidak terkoneksi. Hal ini menarik untuk digali secara mendalam terkait strategi parsial masing-masing kelompok petani karet sehingga dapat melepaskan diri dari jeratan hutang tengkulak secara kolektif; Kedua, permasalahan sosial agama. Subyek dampingan adalah basis umat Islam tradisional yang sedang mengalami pertumbuhan kesadaran akan pentingnya berkah dan kehadiran agama sebagai kontrol perikehidupan mereka. Dalam dasawarsa ini kehidupan beragama di desa ini mengalami kegairahan pasca arus balik sepulang anak-anak mereka setelah nyantri dari pulau Jawa. Namun demikian, belum ditemukan fungsi katalisator antara kegairahan beragama dalam aktivitas ekonomi yang digeluti, yaitu perkebunan karet; Ketiga, permasalahan inklusivitas. Kelompok petani karet yang akan dijadikan obyek penelitian, adalah kelompok petani karet yang berlatarbelakang eks-transmigran yang 
memiliki psikologis terbuka serta siap untuk menerima perubahan tata-niaga seiring terbangunnya kesadaran trasedental beragama.

\section{TINJAUAN PUSTAKA}

Fathoni (2009) dalam risetnya bertajuk Evaluation of Market System and Market Integration for Rubber Cultivation in Jambi Province- Indonesia menyebutkan bahwa terdapat empat pemangku kepentingan di pasar karet dengan peran dan kegiatan yang berbeda. Mereka adalah petani, tengkulak, perusahaan eksportir, dan pemerintah. Untuk petani, tengkulak, dan eksportir, mereka terlibat langsung dalam pasokanrantai karet. Sementara bagi pemerintah hanya melibatkan pengendalian dan pembuatan kebijakan. Berkaitan dengan pengembangan perkebunan petani kecil. Sebagai produsen utama karet alam, petani telah melakukan banyak kegiatan baik kegiatan yang berkaitan dengan budidaya karet atau kegiatan di pasar karet. Mengenai keputusan harga, petani hanya memiliki sedikit atau bahkan sama sekali tidak memiliki posisi tawar di pasar karena harga karet ditentukan oleh para pedagang. Kondisi ini membuat para petani selalu menjadi penerima harga dalam transaksi karet. Pasar karet di Provinsi Jambi bercirikan persaingan monopolistik. Hal ini ditunjukkan oleh keberadaan banyak pedagang di pasar karet. Tidak seperti persaingan sempurna, penjual di bawah persaingan monopolistik membedakan produk kompetitif. Di pasar karet, diferensiasi produk didasarkan pada isi karet kering. Untuk tingkat petani, karet dijual rata-rata kandungan karet kering 37,5\%. Sedangkan untuk pedagang dan eksportir, rata-rata kadar karet kering meningkat hingga 54\% dan 90\%. Secara keseluruhan, perbedaan kadar karet kering mempengaruhi harga jual. Karet kering yang lebih tinggi konten, harga yang lebih baik akan dicapai oleh penjual. Untuk mendapatkan kandungan karet kering yang tinggi, membutuhkan lebih banyak waktu untuk penyimpanan dan pemrosesan. Berdasarkan analisis ko-integrasi menunjukkan bahwa variabel stasioner dan terko-integrasi baik harga karet di Jambi maupun Malaysia. Setelah ko-integrasi dua pasar diperoleh, Uji Granger digunakan untuk menganalisis kausalitas harga di pasar karet Jambi. Dari uji ini, menunjukkan bahwa terdapatkausalitas setidaknya satu arah, bahwa harga Malaysia menyebabkan fluktuasi harga di pasar lelang Jambi. Terdapat cukup bukti untuk menyimpulkan bahwa karet Jambi pasar terintegrasi dengan pasar Malaysia dalam jangka panjang (Fathoni, 2009).

Barus (2018) dalam risetnya yang berjudul "Pelayaran dan Perdagangan Sungai di Karesidenan Jambi 1906-1942” menyebutkan bahwa semenjak abad ke-17, semula Jambi merupakan wilayah penghasil komoditas ekspor seperti lada dan emas. Namun, pada akhir abad ke-19, setelah kolonialisasi Belanda memperkenalkan varietas perkebunan karet, daerah Sumatera tengah ini menjadi sentra penghasil karet alam selain rotan dan kopra. Daerahnya yang tropis dengan banyak sungai, hal ini sangat perpengaruh di dalam pola transportasi angkutan komoditas yang dikembangkan. Dikenal istilah ulu sebagai lokasi komoditas di hulu sungai, dan ilir sebagai tujuan pengiriman komoditas, yaitu pelabuhan. Aktivitas perniagaan ini tidak lepas dari peran dari pedagang Tionghoa sebagai perantara proses produksi di ulu dan perdagangan di ilir (Arman, 2018, hlm. 102; Barus, 2018). 
Haloho dkk (2019) dalam laporan risetnya "Pengarub Harga Karet terhadap Produksi Perkebunan Karet di Provinsi Jambi", menyebutkan bahwa kurun tahun 1990-2016 merupakan puncak perdagangan tertinggi untuk komoditas karet di provinsi Jambi. Hal ini ditandai rekor terjualnya 337.544 ton produksi karet. Sebaliknya, tahun 1990 menempati penjualan terendah pada kisaran 172.199 ton. Dalam kesimpulannya, disebutkan bahwa harga karet di level petani sangat berpengaruh terhadap volume produksi. Sementara, fluktuasi harga karet dunia terbukti tidak berpengaruh signifikan terhadap produksi petani. Harga karet dunia ini, hanya diketahui oleh korporat perkebunan karet sebagai pemain industri. Sementara, dalam kurun waktu 1990-2016, level petani hanya berkutat pada harga karet yang dipatok oleh para korporat pabrikase pengolahan karet rakyat yang mereka kelola (Haloho dkk., 2019).

Teti Kusumawati (2021) dalam riset "Jual Beli Karet Perspektif Hukum Ekonomi Syariah" merumuskan sejumlah temuan: pertama, masyarakat pada level petani sebagian besar merupakan kelompok masyarakat dengan pengetahuan yang minim dalam hal muamalah menurut ajaran Islam. Kedua, karet rakyat dari hasil produksi dijual kepada penadah tengkulak yang disebut tauke dengan harga variatif sesuai dengan kualitas getah karet. Ketiga, peneliti menemukan bahwa terdapat tadlis dari kalangan petani guna mempengaruhi volume produksi mereka dengan mencampurkan partikel non-karet ke dalam hasil produksinya. Hal ini merata dilakukan guna mempengaruhi bertambahnya bobot volume produksi yang berpengaruh terhadap naiknya harga dari para penadah (Teti dkk., 2021).

Sementara, Nugroho (2021) dalam penelitiannya yang mengangkat diskursus "Development Strategies of the Local Auction Market of Agricultural Product in Indonesia" mengungkapkan bahwa inisiasi penyelenggaraan pasar lelang hasil pertanian di Indonesia terbukti memberikan banyak keuntungan. Bagi petani, pasar lelang mampu memasarkan produknya dengan harga tinggi. Kerjasama kelompok tani yang dibentuk juga berkembang dengan baik. Sementara itu, konsumen bisa mendapatkan produk berkualitas tinggi dan industri bisa mendapatkan bahan baku dengan mudah sesuai kadar kualifikasi yang dikehendaki. Dampak terbesar dari lelang pasar adalah terbentuknya sistem perdagangan pertanian secara lebih efisien dan memberikan pendapatan bagi pemerintah. Namun, pasar lelang tampaknya juga menghadapi beberapa tantangan, termasuk kurangnya aturan yang ketat, kurangnya kuantitas dankualitas sumber daya manusia, kurangnya dana dan infrastruktur, persaingan antar pedagang, dan lemahnya dukungan dari para pihak. Untuk mengatasi tantangan ini, pasar lelang perlu menjalin kerjasama yang baik dengan pemasok (petanidan kelompok tani), pembeli (pedagang dan industri), lembaga keuangan (bank, lembaga keuangan lainnya, danswasta), dan pemerintah. (Nugroho, 2021).

\section{METODE PENELITIAN}

Penelitian ini merujuk dari proses pengabdian berbasis komunitas yang dilaksanakan di Desa Rimbo Mulyo Kecamatan Rimbo Bujang Kabupaten Tebo Propinsi Jambi. Bersifat deskriptif dengan jenis penelitian kualitatif, Bogdan dan Taylor menyebutkan jika riset ini menghasilkan paparan data berupa narasi tertulis, atau dapat saja bersifat oral dari orang- 
orang yang perilakunya sedang diteliti. Hakikat penelitian kualitatif lebih pada rangkaian kegiatan sistemik yang dipergunakan guna menemukan teori-teori di lapangan, bukan pembuktian atas suatu teori (Prastowo, 2012). Jadi, locus penelitian deskriptif berbasis kualitatif bertujuan menampilkan suatu data variabel, gejala atau kondisi secara apa adanya. Artinya, tidak sebagai pembuktian teori tertentu atau hipotesis, namun justru guna menemukan suatu teori berbasis lapangan tertentu (Suharsimi, 2006).

Untuk itu, guna merumuskan persoalan dan mengurai permasalahan, peneliti menggunakan metode penelitian studi kasus. Di sini, pembaca akan merasakan denganmelihat rentang data riset hingga akan terbuka menerima hasil kesimpulan penelitian (Daymon \& Holloway, 2002; Yusanto, 2020). Studi kasus, menurut Patton disusun ke dalam tiga tahapan: pertama, pengumpulan data dasar; kedua, menata kasus yang ditemukan ke dalam susunan pemadatan data, meringkas, mengklasifikasi, mengedit dan menyusun ke dalam manageable files yang terjangkau; ketiga, pelaporan secara naratif (Raco, 2018). Sementara, pendekatan penelitian lapangan (field research) dipandang paling relevan sebagai instrumen,guna menghasilkan kepadatan data penelitian, sehingga menghasilkan wawasan analisis informasi literal bagi para praktisi dan akademisi (Morgenbesser \& Weiss, 2018). Pendekatan penelitian ini bertujuan guna menambang langsung data primer dari obyek yang sedang diteliti (Rahayu dkk., 2020).

Guna menambang informasi secara komprehensif, penelitian ini berbasis pada data primer yang bersumber pada realitas faktual obyek penelitian. Proses penggalian data dilakukan dengan metode wawancara, pengamatan langsung (observasi) dan dokumentasi. Adapun kelengkapan informasi, digunakan data nominal riset yang difungsikan sebagai data sekunder dengan mereduksi laporan, jurnal dan dokumentasi resmi yang relevan dari sumbersumber otoritatif secara time series data (Situmorang dkk., 2010). Dalam riset kualitatif, preferensi metode analisis data sangat dipengaruhi research questions, research strategies dan theoretical frameworks (Chariri, 2009) dan pemodelan grass root (Muhadjir, 2011). Dalam analisis data, peneliti menempuh sejumlah tahapan: pertama, data reduction yang kegiatannya meliputi mengorganisir data ke dalam sejumlah pola dan coding data. Kedua, pemahaman atas coding data dan mengujinya; ketiga, interpretasi data baik menggunakan strategi ideal types, path dependencyand contingency maupun domain analysis (Neuman, 2003).

\section{HASIL DAN DISKUSI}

\section{Historiografi Transmigrasi di Rimbo Bujang}

Dalam perspektif historiografi, proses transmigrasi penduduk pulau Jawa ke Sumatera dan beberapa negara mancanegara dimulai semenjak tahun 1905. Kolonialisasi bumi Nusantara oleh kerajaan Belanda menginisiasi program migrasi bahkan hingga jauh ke benua Afrika, Amerika dan beberapa wilayah di kepulauan Pasifik. Program kependudukan politik etis tersebut, setidaknya dilatarbelakangi oleh dua sebab mendasar, yaitu guna mendapatkan pekerja giat dengan upah rendah dan atau pengasingan karena 
faktor politik. Kerajaan Belanda mencatat setidaknya terdapat 1.227.601 jiwa yang telah dimigrasikan hingga tahun 1978 (Purnamasari, 2021; Yulmardi, 2019). Dengan program Pembangunan Lima Tahun (Pelita) ke-1, ke-2 dan ke-3 pada tahun 1983, rezim Orde Baru telah berhasil mentransmigrasikan 500.000 kepala keluarga penduduk Jawa ke pulau Sumatera, tepatnya Lampung, Sumatera Selatan, Jambi dan Sumatera Barat. Hingga akhir Orde Baru (Pelita ke-6), rata-rata jumlah transmigran yang berhasil disebar sebanyak 350.064 kepala keluarga per tahun. Sementara, pada era Reformasi dalam rentang tahun 2000-2004 hanya tersebar 87.571 kepala keluarga per tahunnya (Yulmardi, 2019).

Tabel 1. Kronik Penempatan Transmigran di Kecamatan Rimbo Bujang (Bappeda, 2014)

\begin{tabular}{cllcl}
\hline $\begin{array}{c}\text { Notasi } \\
\text { Unit }\end{array}$ & Lokasi Penempatan & $\begin{array}{c}\text { Tahun } \\
\text { Penempatan }\end{array}$ & $\begin{array}{c}\text { Kepala } \\
\text { Keluarga }\end{array}$ & Jiwa \\
\hline $\mathbf{1}$ & Desa Perintis & $1975-1976$ & 500 & 2.068 \\
$\mathbf{2}$ & Kelurahan Wirotho Agung & $1976-1977$ & 502 & 2.441 \\
$\mathbf{3}$ & Desa Rimbo Mulyo & $1976-1977$ & 500 & 2.135 \\
$\mathbf{4}$ & Desa Purwoharjo & $1976-1977$ & 501 & 2.410 \\
$\mathbf{5}$ & Desa Tegal Arum & $1976-1977$ & 497 & 2.615 \\
$\mathbf{6}$ & Desa Tirta Kencana & $1977-1978$ & 388 & 1.877 \\
$\mathbf{7}$ & Desa Sapta Mulia & $1977-1978$ & 216 & 1.035 \\
$\mathbf{8}$ & Desa Sukamaju & $1977-1978$ & 468 & 2.099 \\
$\mathbf{8}$ & Desa Sukamaju A & $1977-1978$ & 154 & 813 \\
$\mathbf{9}$ & Desa Suka Damai & $1977-1978$ & 468 & 2.271 \\
$\mathbf{1 0}$ & Desa Wanareja & $1977-1978$ & 300 & 1.427 \\
$\mathbf{1 1}$ & Desa Sumber Sari & $1978-1979$ & 348 & 1.782 \\
$\mathbf{1 2}$ & Desa Sido Rukun & $1978-1979$ & 499 & 2.158 \\
$\mathbf{1 5}$ & Desa Rimbo Ilir & $1978-1979$ & 560 & 2.442 \\
$\mathbf{-}$ & Desa Pematang Sapat & 1980 & 656 & 2.236 \\
\hline
\end{tabular}

Di lokasi Rimbo Bujang, penempatan para transmigran dimulai pada tahun 19751977. Penempatan generasi pertama ini berjumlah 21.254 jiwa dari 9.974 kepala keluarga. Adapun komposisi 79,76\% merupakan kepala keluarga berjenis kelamin laki-laki, dan sebesar 20,24\% perempuan. Jumlah tersebut merupakan bagian dari 83.514 kepala keluarga membawahi 327.674 jiwa transmigran yang disebarkan seantero propinsi Jambi semenjak Pelita ke-1 hingga Orde Baru berakhir. Para transmigran Rimbo Bujang generasi pertama, berasal dari sejumlah daerah di pulau Jawa, dengan perincian $68 \mathrm{KK}$ dari DKI Jakarta, $520 \mathrm{KK}$ dari Jawa Barat, 7.212 KK dari Jawa Tengah, $588 \mathrm{KK}$ dari Jawa Timur dan 406 KK dari D.I Yogyakarta (Yulmardi, 2019). Pada mulanya, penempatan para transmigran di kecamatan Rimbo Bujang berjumlah 500 kepala keluarga yang membawahi 2.068 jiwa berlokasi di Desa Perintis. Desa-desa di kecamatan Rimbo Bujang kemudian lebih dikenal dengan notasi Unit-1 sampai Unit-15, minus Unit-14 yang masuk ke dalam wilayah kabupaten Muara Bungo dan Unit-13 yang ditiadakan notasinya 
tanpa keterangan. Kawasan kecamatan Rimbo Bujang, sebelum pemekaran, mencakupwilayah pengembangan kawasan Alai Ilir, yang semula bernama Desa Rimbo Ilir, dengan notasi Blok-A sampai F.

Adapun Desa Pematang Sapat, lebih merupakan pemukiman para pekerjadan karyawan PT. Perkebunan Nusantara VI. Desa ini dihuni penduduk berdasarkan kompleks-kompleks pemukiman dengan komposisi etnis yang lebih variatif dari Jawa Timur, Jawa Barat, Sumatera Utara, Sumatera Selatan, Sumatera Barat dan penduduk lokal Jambi, ketimbang desa-desa berbasis transmigrasi lainnya (Sijabat dkk., 2021). Pada awal penempatan, desa ini telah memiliki fasilitas umum paling lengkap, seperti aliran air, poliklinik, sekolah dan listrik. Fasilitas-fasilitas asasi tersebut diperoleh dari perusahaan tempat mereka bekerja. Desa Pematang Sapat merupakan satu-satunya kawasan yang berbasis pekerja perkebunan, bukan petani dengan lahan sendiri. Namun demikian, setelah 40 tahun masa penempatan transmigrasi, kawasanini yang justru mengalamistagnasi baik secara ekonomi maupun psikologis masyarakatnya. Berbeda dengan eks-lokasi transmigrasi yang mengalami perkembangan secara signifikan. Bahkan kecamatan Rimbo Bujang ditahbiskan sebagai salah satu program transmigrasi nasional yang berkatagori sukses.

\section{Periodisasi Perdagangan Karet Rakyat di Rimbo Bujang}

Terdapat periodisasi model perniagaan karet rakyat di Kecamatan Rimbo Bujang. Hal ini dapat diklasifikasikan ke dalam tiga fase besar, antara lain sebagaimana berikut ini: Fase pertama, pada kurun waktu 1980-1990an, perdagangan karet di kalangan petani transmigran lebih berbentuk akad musyarakah. Melalui Koperasi Unit Desa (KUD) yang dibentuk di setiap desa, hasil produksi karet petani dibeli untuk diolah oleh PTP Nusantara VI dari unit-unit Tempat Pengolahan Hasil (TPH) yang tersebar berdasarkan sub-Rukun Warga (RW) di setiap desa. Distribusi ini terbilang efektif dan efisien mengingat dalam praktek perniagaannya didukung penuh pihak aparat keamanan, ABRI pada dekade itu. Harga yang diberlakukan adalah harga KUD atas penetapan pihak PTP Nusantara VI. Aktivitas membeli di luar mekanisme KUD dianggap illegal dan akan mendapat tindakan represif dari aparat di tingkat desa (Babinsa). Para pembeli produksi karet petani illegal, menjual hasil pembeliannya dari para transmigran kepada pabrikpabrik swastadi luar Provinsi Jambi, mereka kemudian dikenal dengan sebutan tengkulak. Modus tengkulak men dalam menyelengarakan perniagaannya adalah dengan menyediakan pinjaman lunak kepada petani dengan angsuran berupa hasil produksi karet dengan selisih harga beli lebih mahal jika dibandingkan dengan harga beli KUD, dalam hal ini PTP Nusantara VI. Berbagai kemudahan yang ditawarkan oleh para tengkulak pada akhirnya menyebabkan beralihnya preferensi penjualan hasil produksipetani transmigran kepada mereka. Demikian sejarah paling awal terbentuknya harga dan pasar produksi karet produksi rakyat di Kecamatan Rimbo Bujang Kabupaten Tebo Provinsi Jambi. 
Fase kedua, pada kurun waktu 1990-2010an, ditandai dengan hegemoni para pemodal yang berperan sebagai tengkulak. Transisi peta pasar bahan olahan karet (bokar) ini, ditegaskan dengan keluarnya PTP Nusantara VI dari sistem pasar bahan olahan karet rakyat. Kondisi ini setidaknya dilatarbelakangi oleh dua perkembangan; pertama, dugaan tercapainya break event point atas pembiayaan transmigrasi. Kedua, mulai berproduksinya perkebunan karet milik PTP Nusantara VI sehingga tercukupinya bahan olahan karet tanpa tergantung lagi terhadap Hasil Perkebunan Inti Rakyat (PIR). Dalam perspektif kinerja dan besaran modal, tengkulak sendiri di bagi ke dalam dua katagori. Pertama, tengkulak besar pemegang hak delivery order (DO) sebagai distributor sekaligus pemegang saham pada pabrik-pabrik milik swasta. Kedua, tengkulak kecil dalam skala pedesaan yang melakukan pengepulan dan pembelian langsung ke masyarakat untuk didistribusikan kepada pabrik-pabrik dengan lisensi tengkulak pemegang delivery order (DO). Tengkulak kecil selama ini mendapatkan modalnyadari tengkulak besar untuk disebarkan kepada petani. Sementara, rata-rata untuk mendapatkan izin delivery order (DO), seorang tengkulak besar setidaknya harus menginvestasikan saham pada pabrik pengolahan karet sebesar lima milyar rupiah.

Regulasi yang sangat longgar, pada gilirannya menstimulasi pada sistem perniagaan yang membuka keleluasaan bagi para pemodal. Mekanisme yang dibangun guna mengikat para petani eks-transmigran adalah dengan cara memberikan hutang lunak tanpa jaminan dengan syarat penjualan kepada tengkulak yang bersangkutan dengan harga terikat dan spesifikasi getah karet tertentu. Dalam proses penelitian, para tengkulak besar yang memiliki delivery order (DO) ini, terkesan lebih tertutup dan sulit untuk diakses. Di samping itu, mekanisme perniagaan karet yang diselenggarakan oleh tengkulak adalah berikut ini:

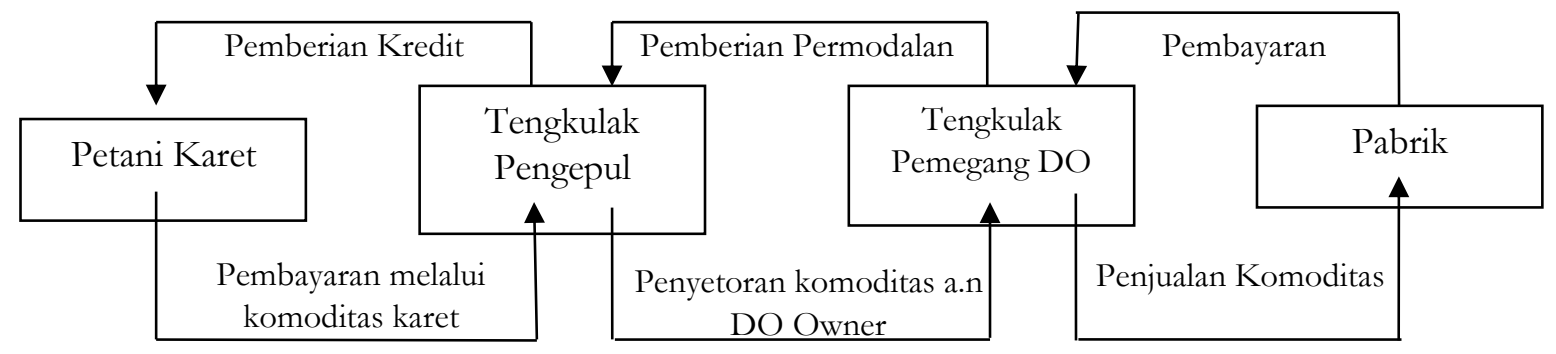

Gambar 1. Alur Mekanisme Perniagaan Karet Pola Tengkulak

Di ranah praksis, patut diulas, secara umum mekanisme perdagangan yang dikembangkan oleh kalangan tengkulak adalah dengan terlebih dahulu menyebarkan hutang tanpa agunan kepada petanidengan pembayaran diangsur melalui hasil produksi, yaitu karet. Di sini, petani sendiri tidak pernah mengetahui harga karet yang sebenarnya. Dalam proses penimbangan hingga pembayaran, penetapan harga harga beli produksi karet perkilogramnya merupakan hak preogratif tengkulak. Petani telah kehilangan hak tawarnya akibat hutangnya kepada tengkulak. Demikianlah harga dasar terbentuk di tingkat dasar petani karet pada fase kedua. Selain matinya daya tawar petani, pengurangan 
bobot timbangan secara sepihak, penggunaan timbangan yang tidak terstandarisasi, pada gilirannya sering menimbulkan konflik antara petani dengan buruh tengkulak. Dalam perspektif politik ekonomi, hegemoni tengkulak pada perkembangan berikutnya semakin kuat. Hal ini ditandai dengan keterlibatan tengkulak besar sebagai sponsor sejumlah legislator yang memainkan peranan regulatif guna 'melindungi' tengkulak di parlemen dan pemerintahan. Fase ini dirasakan sebagai klimaks ironi petani karet yang menempatkan posisi mereka pada titik nadir, seiring dengan bubarnya satu demi satu Koperasi Unit Desa (KUD) di seluruh pedesaan ketika berhadapan dengan Badan Usaha Milik Desa (BUMDes).

Fase ketiga, pada kurun 2010-2020an, perkembangan model perniagaan karet rakyat ditandai mentasnya sejumlah petani dalam wilayah tertentu dari jeratan hutang tengkulak. Namun jumlahnya masih terbilang kecil. Sejumlah petani karet ini kemudian saling terkoneksi dan membentuk semacam kelompok petani penjual dan menyelenggarakan mekanisme lelang hasil produksi kelompok mereka kepada sejumlah tengkulak serta menjualnya pada penawaran harga tertinggi. Fase ini ditandai dengan surutnya produksi karet rakyat eks-transmigran dan mengganti varietas yang ada dengan tanaman kelapa sawit.

\section{Desa Rimbo Mulyo; Refleksi Perniagaan Karet Rakyat di Rimbo Bujang}

Desa Rimbo Mulyo merupakan salah satu desa yang berada di Kecamatan Rimbo Bujang, Kabupaten Tebo, Provinsi Jambi. Desa Rimbo Mulyo merupakan desa yang berada di sebelah utara berbatasan dengan Kelurahan Wirotho Agung, sebelah Selatan berbatasan dengan Desa Pematang Sapat dan Kabupaten Bungo, sebelah Timur berbatasan dengan Desa Tirta Kencana dan Sapta Mulia, dan sebelah Barat berbatasan dengan Desa Sido Rukun Kecamatan Rimbo Ulu. Jarak Desa Rimbo Mulyo ke ibukota kecamatan $\pm 10 \mathrm{~km}$, jarak ke ibukota kabupaten $\pm 60 \mathrm{~km}$, sedangkan jarak ke ibukota provinsi berjarak $\pm 270 \mathrm{~km}$. Secara geografis, Desa Rimbo Mulyo terletak pada 10-20 lintang selatan dan 1020 bujur timur. Desa ini memiliki luas wilayah 55,50 $\mathrm{Km}^{2}$ atau 5.550 Ha. Desa Rimbo Mulyo menjadi salah satu desa yang menjadi destinasirelokasi transmigran dari pulau Jawa di Kabupaten Tebo.

Desa Rimbo Mulyo secara administratif terdiri dari 49 Rukun Tetangga (RT) dan 8 Rukun Warga (RW) yang terbentuk dan terpetakan berdasarkan kebijakan pembentukan desa di bawah Kecamatan Rimbo Bujang. Hal tersebut sebagaimana termaktub di dalam Peraturan Pemerintah Nomor 60 Tahun 1991 Pasal 7. Pada tahun 2000-an penduduk Desa Rimbo Mulyo menjadi semakin meningkat. Transmigran yang berasal dari Jawa Tengah menjadi penduduk pendatang yang jumlahnya terbanyak $\pm 2.038 \mathrm{KK}$. Berdasarkan sejarah ketransmigrasiannya, Desa Rimbo Mulyo merupakan salah satu Unit Pemukiman Transmigrasi (UPT) Rimbo Bujang dengan notasi Unit III Rimbo Bujang. Tahun awal penempatan transmigran di lokasi ini adalah pada tahun 1976, dengan jumlah 
penempatan sebanyak $500 \mathrm{KK}$ (2.135 jiwa). Transmigran tersebut berasal dari Jawa Tengah (474 KK) dan Jawa Timur (26 KK).

Tidak adanya rujukan regulasi daerah yang mengatur perdagangan karet di Desa Rimbo Mulyo pasca reformasi, dimana semula petani wajib menjual produksi karetnya melalui Koperasi Unit Desa (KUD) Mukti Jaya Desa Rimbo Mulyo. Semenjak itu, mekanisme perdagangan komoditas karetnya ada terbilang bebas tanpa kehadiran pemerintah, baik pusat maupun daerah (N. Nisman, komunikasi pribadi, 15 April 2018). Setelah pudarnya peran operasional Koperasi Unit Desa (KUD) Mukti Jaya Desa Rimbo Mulyo mulai menstimulasi bermunculannya para pemodal dari luar Desa Rimbo Mulyo. Dalam prakteknya, terdapat dua pemodal besar warga keturunan yang masuk dan membangun basis pengepulan komoditas karet di Desa Rimbo Mulyo, yaitu Apin (38 Tahun) berbasis di Jalan Pahlawan (masuk kewilayahan Jalan Tulang Bawang/22) dan Atong (43 Tahun) di Jalan Pahlawan (masuk kawasan Jalan Kenali/14). Sejauh ini Badan Usaha Milik Desa (BUMDes) Mukti Jaya yang didirikan belum mampu menjangkau pembelian karet dari petani atau sebagai subsitusi peranan tengkulak yang beroperasi di dalam desa.Petani karet eks-transmigran di Desa Rimbo Mulyo semenjak tahun 1990an mulai menyelenggarakan perdagangan (jual-beli) karet langsung kepada tengkulak lokal, baik kepada mereka yang satu jalur (istilah untuk ruas jalan desa), maupun dari jalur lain dari luar warga Rimbo Mulyo. Pada perkembangannya, ketika harga karet jatuh di tahun 2010an, Pemerintah Desa Rimbo Mulyo justru menstimulasi komoditas "ekspor" nonkaret kepada masyarakat berupa arang kayu karet dan nilam. Namun demikian program ini, belum mendapat respon yang signifikan dari masyarakat.

Dari penelitian yang dilakukan, pada tahap awal, komposisi tengkulak yang beroperasi di Desa Rimbo Mulyo terbilang tidak merata. Dalam wawancara kepada tengkulak, tercatat beberapa temuan bahwa sebagian besar tengkulak yang sempat marak pasca non-aktifnya KUD Mukti Jaya, tak lama gulung tikar akibat menurunnya produksi karet petani dan semakin kompetitifnya kriteria produksi yang dapat masuk ke pabrik, baik yang berada di Pabrik Jujuhan Sumatera Barat maupun pabrik yang berada di Muara Bungo. Artinya, sesungguhnya hanya tinggal terdapat beberapa gelintir tengkulak saja yang masih beroperasi (Suyadi, komunikasi pribadi, 23 Mei 2018). Adapun katagori tengkulak tersebut sebagai berikut:

Tabe1 2. Jumlah Tengkulak Karet di Desa Rimbo Mulyo

\begin{tabular}{ccccc}
\hline $\begin{array}{c}\text { Notasi } \\
\text { Jalan }\end{array}$ & $\begin{array}{c}\text { Nama } \\
\text { Jalan }\end{array}$ & $\begin{array}{c}\text { Tengkulak } \\
\text { Pengepul }\end{array}$ & $\begin{array}{c}\text { Tengkulak } \\
\text { Pemegang } \\
\text { Delivery Order }\end{array}$ & $\begin{array}{c}\text { Kelompok } \\
\text { Tani }\end{array}$ \\
\hline 14 & Malonas & 3 & 1 & 0 \\
15 & Lunang & 2 & 0 & 2 \\
16 & Kalena & 3 & 0 & 2 \\
17 & Kupang & 2 & 0 & 0 \\
18 & Kinali & 1 & 0 & 0 \\
19 & Sepaku & 2 & 0 & 0
\end{tabular}




\begin{tabular}{ccccc}
\hline $\begin{array}{c}\text { Notasi } \\
\text { Jalan }\end{array}$ & $\begin{array}{c}\text { Nama } \\
\text { Jalan }\end{array}$ & $\begin{array}{c}\text { Tengkulak } \\
\text { Pengepul }\end{array}$ & $\begin{array}{c}\text { Tengkulak } \\
\text { Pemegang } \\
\text { Delivery Order }\end{array}$ & $\begin{array}{c}\text { Kelompok } \\
\text { Tani }\end{array}$ \\
\hline 20 & Jujuhan & 3 & 0 & 2 \\
21 & Kendari & 2 & 0 & 0 \\
22 & Tulangbawang & 2 & 1 & 2 \\
23 & Cintamanis & 3 & 1 & 2 \\
24 & Berabai & 2 & 0 & 1 \\
\hline
\end{tabular}

Sejumlah problematika petani eks-transmigran, mengaku keberatan dengan sistem kolektivitas petani karet. Namun demikian dari masalah-masalah yang mengemuka, kebanyakan bahwa hilangnya daya tawar mereka, lebih merupakan dampak keterikatan atas utang kepada para tengkulak. Keberatan yang lain juga muncul dari anggota masyarakat yang selama ini bekerja sebagai buruh angkut tengkulak. Teknis perniagaan kelompok tani ini adalah dengan tidak terlibat hutang piutang bersyarat kepada para tengkulak dengan sejumlah potongan sepihak dan permainan timbangan. Di sisi lain, dengan kolektivitas petani maka sistem penjualan dari para petani kepada para tengkulak adalah dengan sistem lelang. Dalam pengamatan peneliti, tengkulak pemodal dari luar daerah cenderung lebih lunak dalam memberikan pinjaman kepada petani dengan tawaran harga tinggi, jika dibandingkan dengan harga tengkulak pengepul lokal. Selain itu, secara manajemen dan fasilitas standar perusahaan, para pemodal keturunan dari luar desa terlihat lebih mapan dan tertata.

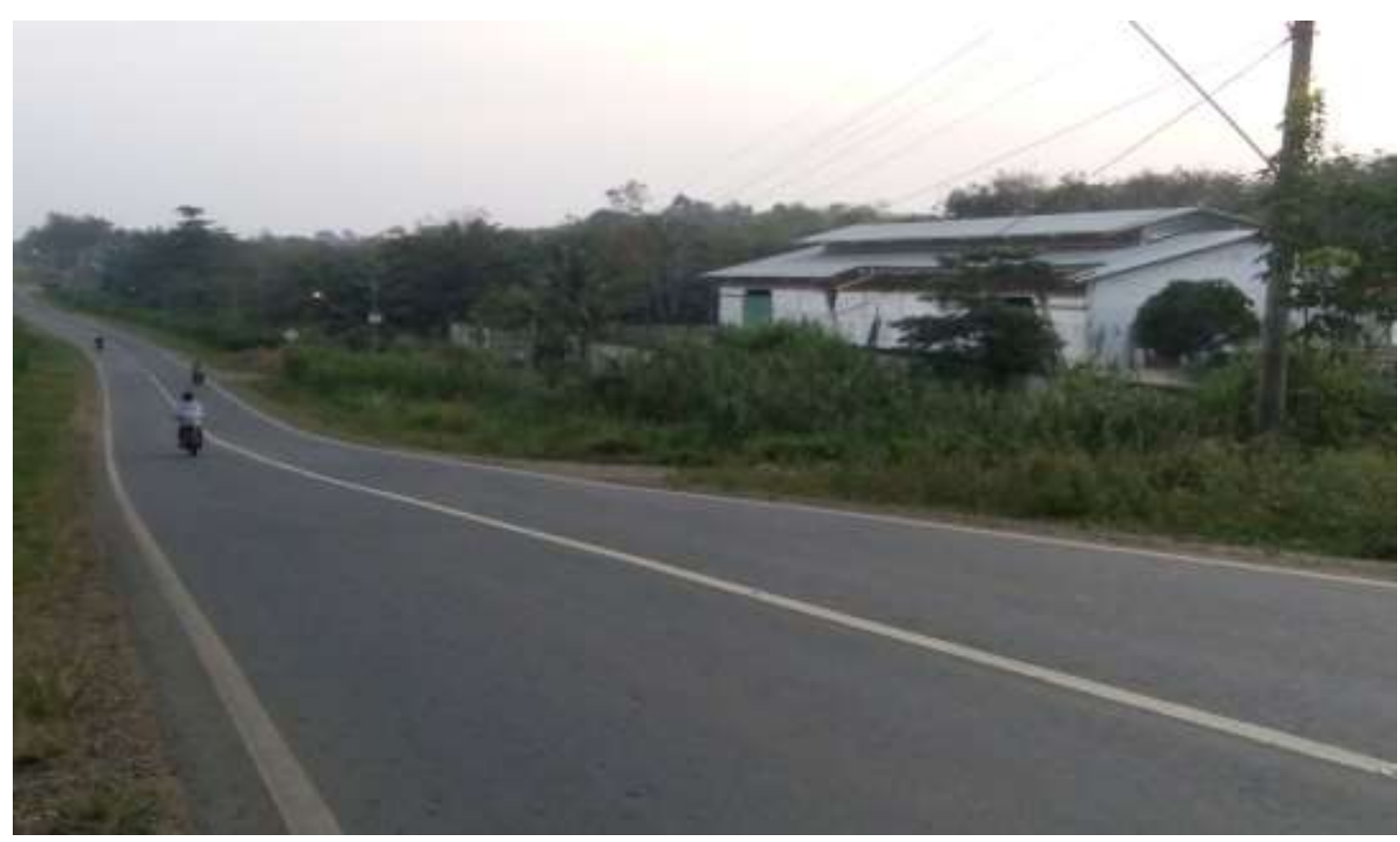

Gambar 2. Gudang Karet Apin di Jalan Poros (Kawasan Tulang Bawang) 


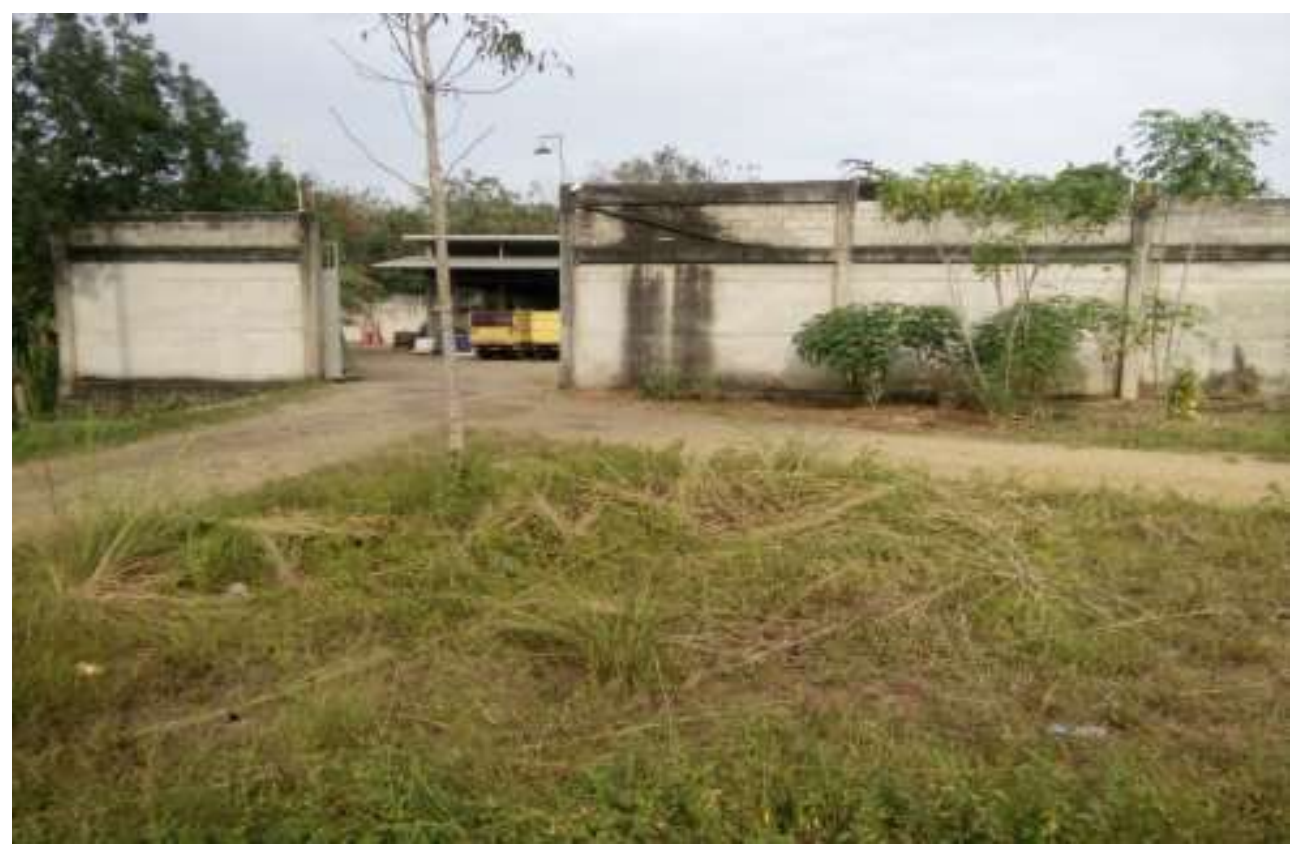

Gambar 3. Gudang Karet Atong di Jalan Poros (Kawasan Kenali)

\section{Diskusi}

Sistem perniagaan syariah atau yang berkesesuaian dengan prinsip syariat Islam pada hakekatnya adalah terhindarnya umat Islam dalam bermuamalah dari hal-hal yang dilarang oleh hukum Islam. Dalam hal ini seperti riba, maysir, gharar, tadlis dan zalim. Praktek perniagaan karet yang selama ini berlangsung di Desa Rimbo Mulyo dan Kecamatan Rimbo Bujang pada umumnya adalah berlangsungnya hutang bersyarat dari tengkulak kepada petani yang merugikan petani, selain permainan timbangan dan potongan sepihak dari tengkulak atas volume berat komoditas karet. Di sisi lain, petani yang merasa dirugikan kemudian tergerak untuk merekayasa komoditas karet yang mereka jual atas sistem yang tidak berpihak kepada mereka, dengan mencampurkan partikel non-karet dalam produksi mereka seperti tanah, air dan pasir.

Merujuk pada pemetaan komunitas petani karet eks-transmigran di Desa Rimbo Mulyo, maka pembentukan kelompok tani karet merupakan dinamika perniagaan yang dinilai mendongkrak daya tawar petani atas hegemoni tengkulak. Komoditas yang pada awalnya langsung dijual kepada tengkulak oleh individu petani, maka dengan mekanisme kelompok tani, hal ini dapat diantisipasi. Medel perjualan dengan kelompok tani ini, secara syariat juga ternyata cenderung menyelamatkan petani dari perilaku riba dan tadlis yang selama ini berlangsung antara petani dan tengkulak. 


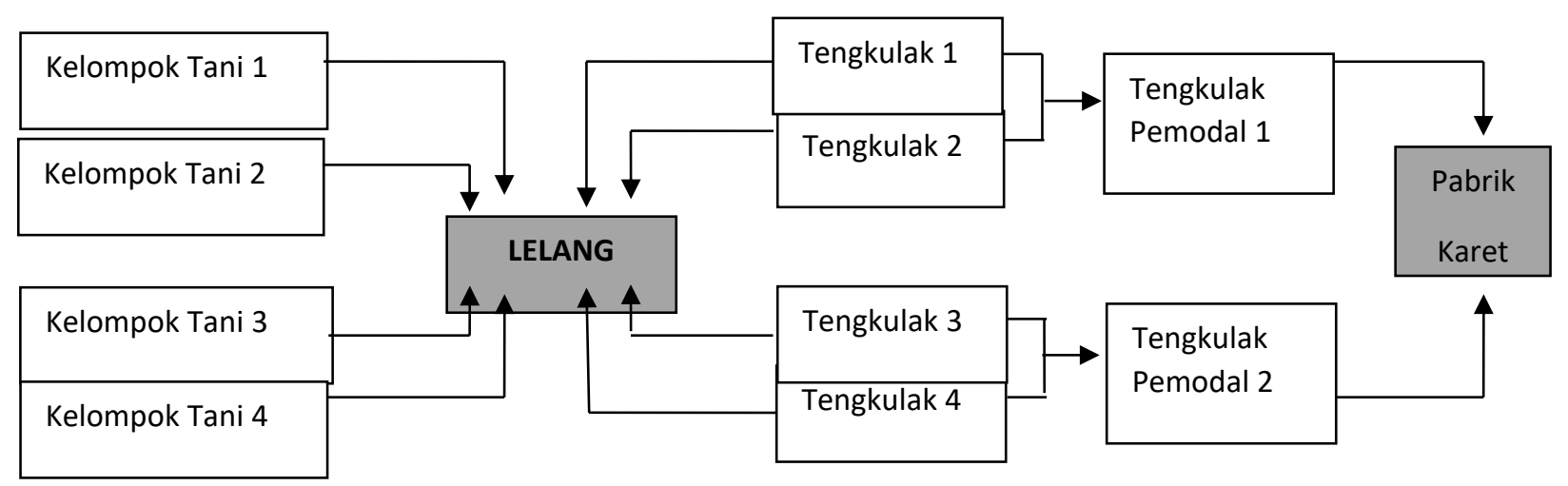

Gambar 4. Mekanisme Perniagaan Karet Kelompok

Tiadanya rujukan regulasi daerah yang mengatur perdagangan karet di Desa Rimbo Mulyo pasca reformasi, dimana petani wajib menjual produksi karetnya melalui Koperasi Unit Desa (KUD) Mukti Jaya Desa Rimbo Mulyo. Maka semenjak itu, mekanisme perdagangan komoditas karet tergolong tercipta pasar bebas tanpa kehadiran pemerintah, baik pusat maupun daerah. Pudarnya peran operasional Koperasi Unit Desa (KUD) Mukti Jaya Desa Rimbo Mulyo menstimulasi bermunculannya para pemodal dari luar Desa Rimbo Mulyo. Dalam prakteknya terdapat dua pemodal besar warga keturunan yang masuk dan membangun basis pengepulan komoditas karet di Desa Rimbo Mulyo, yaitu Apin (38 Tahun) berbasis di Jalan Pahlawan (masuk kewilayahan Jalan Tulang Bawang/22) dan Atong (43 Tahun) di Jalan Pahlawan (masuk kewilayahan Jalan Malonas/14). Sejauh` ini Badan Usaha Milik Desa (BUMDes) Mukti Jaya yang didirikan belum mampu menjangkau pembelian karet dari petani atau sebagai subsitusi peranan tengkulak yang beroperasi di dalam desa mereka. Adapun mekanisme perniagaan karet yang diselenggarakan oleh para tengkulak adalah sebagaimana berikut in i:

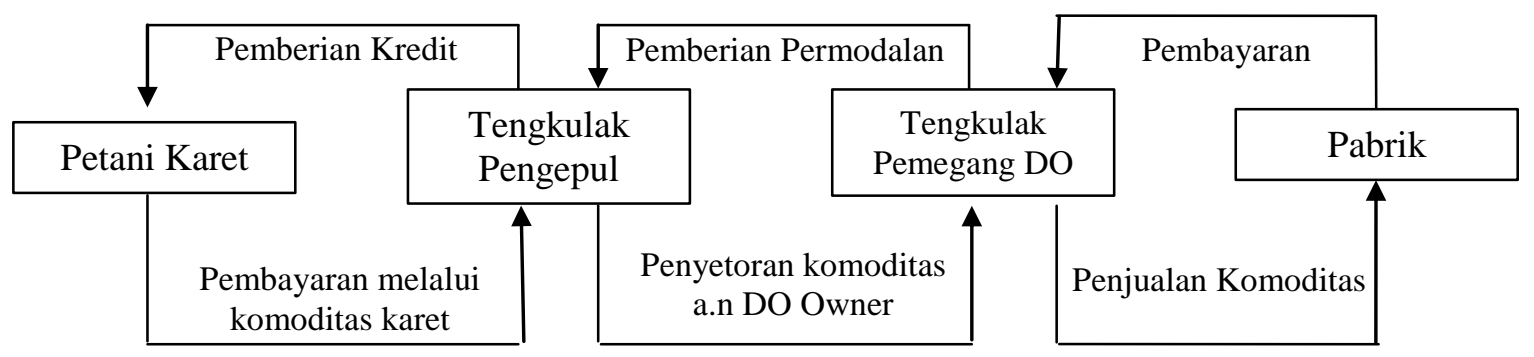

Gambar 5. Alur Mekanisme Perniagaan Karet Pola Tengkulak

Petani karet eks-transmigran di Desa Rimbo Mulyo sejauh ini menyelenggarakan perdagangan (jual-beli) karet langsung kepada tengkulak lokal, baik mereka yang satu jalur/jalan maupun dari jalur/jalan lain dari warga Rimbo Mulyo. Dalam demografi di atas, sebagian besar mencakup 95\% penduduk Desa Rimbo Mulyo adalah petani karet dan kelapa sawit. Sementara sisanya adalah Aparatur Sipil Negara dan buruh. Dalam pengamatan awal tim pendampingan, terdapat kondisi umum kelompok petani karet di 
Desa Rimbo Mulyo Kecamatan Rimbo Bujang Kabupaten Tebo Provinsi Jambi. Dalam hal ini adalah sebagai berikut ini:

a. Masih banyak petani terjerat dalam hutang tengkulak. Hal ini dalam pengamatan sementara lebih disebabkan oleh latarbelakang pendidikan yang rendah dan sistem perdagangan yang tidak berpihak kepada petani karet serta minimnya kesadaran kolektif untuk kesejahteraan senasib di kalangan petani karet dalam setiap submasyarakatnya;

b. Kelompok petani masih bersifat komunitas tak terkoordinir dan masih bersifat tradisional baik secara tata kelola manajemen, keuangan dan administrasi serta tidak memiliki jaringan komunikasi antara satu kelompok petani dengan kelompok petani lainnya;

c. Tidak adanya pendampingan dan pengawasan perdagangan dari pemerintah daerah, tiadanya perlindungan aparat keamanan atas proses produksi petani, nihilnya penyuluhan teknik perkebunan pasca transmigrasi serta wawasan agama keagronomian.

Sejauh ini Pemerintah Desa Rimbo Mulyo justru menstimulasi komoditas “ekspor" non-karet kepada masyarakat berupa arang kayu karet dan nilam. Namun demikian program ini, merujuk datainforman, belum mendapat respon yang signifikan dari masyarakat. Artinya Pemerintah Desa Rimbo Mulyo belum memberikan fokus pemberdayaan yang memadai atas komoditas dasar atas warga masyarakatnya. Dalam hal ini petani eks-transmigran mampu mengaplikasikan mekanisme kolektif berbasis lelang sehingga menaikan daya tawar produksi mereka kepada tengkulak. Dalam hal ini adalah sebagaimana berikut ini:

\section{KESIMPULAN}

Kecamatan Rimbo Bujang merupakan bagian kewilayahan Kabupaten Tebo Propinsi Jambi. Kawasan ini merupakan lokasi yang dinilai berhasil oleh pemerintah. Program transmigrasi yang dilakukan pada kurun 1975 diarahkan pada pengembangan perkebunan tanaman karet. Model perniagaan karet rentang tahun 1980-2020 yang kemudian berkembang dapat di bagi kepada tiga fase: pertama, perniagaan masyarakat transmigran dengan pemerintah pada kurun tahun 1980-1990. Kedua, perniagaan masyarakat eks-transmigran dengan kehadiran pihak swasta, baik dari koperasi unit desa maupun perorangan yang disebut dengan istilah tengkulak pada kurun tahun 1990-2010. Ketiga, perniagaan masyarakat dengan pola kelompok tani karet rakyat dengan model lelang dengan para tengkulak pada kurun tahun 2010-2020.

Secara umum mekanisme perdagangan yang dikembangkan oleh kalangan tengkulak sebelum pola lelang, adalah dengan terlebih dahulu menyebarkan hutang tanpa agunan kepada petani dengan pembayaran diangsur melalui hasil produksi, yaitu karet. Di sini, petani sendiri tidak pernah mengetahui harga karet yang sebenarnya. Dalam proses penimbangan hingga 
pembayaran, penetapan harga harga beli produksi karet per kilogramnya merupakan hak preogratif tengkulak, sehingga petani kehilangan hak tawarnya akibat hutangnya tersebut. Demikianlah harga dasar terbentuk di tingkat dasar petani karet pada semenjak fase kedua. Selain matinya daya tawar petani, pengurangan bobot timbangan secara sepihak, penggunaan timbangan yang tidak terstandarisasi,menstimulasi moral hazzard petani dan menimbulkan konflik antara petani dengan buruh tengkulak.

Pada sistem perniagaan ijon yang diselenggarakan oleh tengkulak menyebabkan beberapa implikasi deviasi syari'at, seperti: terjadinya pengambilan manfaat atas hutang oleh tengkulak atas petani, sepertimanipulasi timbangan oleh buruh timbang untuk mempengaruhi nilai bobot komoditas karet, pemotongan angka timbangan sepihak oleh tengkulak atas bobot komoditas milik petani karet, rekayasa dan manipulasi bobot komoditas oleh petani karet guna mensiasati berat timbangan melalui kadar air dan material non-karet ke dalam komoditas, serta pengabaian kewajiban zakat komoditas bagi petani dan zakat perdagangan bagi tengkulak.

\section{REFERENSI}

Andriany, D. (2015). Pengembangan Model Pendekatan Partisipatif dalam Memberdayakan Masyarakat Miskin Kota Medan untuk Memperbaiki Taraf Hidup. Seminar Nasional Ekonomi Manajemen dan Akuntansi (SNEMA), 30-39.

Arman, D. (2018). Perdagangan Lada di Jambi Abad XVI-XVIII. Handep, 1(2), 81-106.

Bappeda, Prop. J. (2014). Jambi in Figures 2014 (Statistik No. 125; Jambi dalam Angka). Bappeda Propinsi Jambi. https://bappeda.jambiprov.go.id/welcome/download_file_dokumen_tambahan/ba b_2.pdf

Barus, E. R. M. (2018). Pelayaran dan Perdagangan Sungai Di Karesidenan Jambi 1906-1942= The Shipping and Trading of River in the Residency of Jambi 1906-1942.

BPS, P. J. (2021). Petani Tanaman Perkebunan 2016-2018. Badan Pusat Statistik. https://jambi.bps.go.id/indicator/54/893/1/petani-tanaman-perkebunan-.html

Chariri, A. (2009). Landasan filsafat dan metode penelitian kualitatif.

Daymon, C., \& Holloway, I. (2002). Metode-Metode Riset Kualitatif dalam Public Relation \& Marketing Communications. PT. Bentang Pustaka.

Fathoni, Z. (2009). Evaluation of Market system and Market integration for Rubber cultivation in Jambi Province-Indonesia. Wageningen University and Research.

Haloho, A. F., Mara, A., \& Damayanti, Y. (2019). Pengaruh Harga Karet terhadap Produksi Perkebunan Karet di Provinsi Jambi. Jurnal Ilmiah Sosio-Ekonomika Bisnis, 22(2), 2435. 
Hatu, R. (2010). Pemberdayaan dan Pendampingan Sosial dalam Masyarakat (Suatu Kajian Teortis). Jurnal Inovasi, 7(04).

Kementan RI, K. R. (2021). Luas Areal Karet Menurut Provinsi di Indonesia, 2017-2021. Kementerian Pertanian Republik Indonesia. https://www.pertanian.go.id/home/index.php?show=repo\&fileNum=228

Lindayanti, L. (1993). Perkebunan Karet Rakyat di Jambi pada Masa Pemerintahan Hindia Belanda 1906-1940. Universitas Andalas. http:/ / katalog.pustaka.unand.ac.id//index.php?p=show_detail\&id=18035

Morgenbesser, L., \& Weiss, M. L. (2018). Survive and thrive: Field research in authoritarian Southeast Asia. Asian Studies Review, 42(3), 385-403.

Muhadjir, N. (2011). Metodologi Penelitian(VI). Penerbit Rake Sarasin.

Neuman, W. L. (2003). Social Research Method: Qualitative and Quantitative Approaches. MA: Allyn and Bacon.

Nisman, N. (2018, April 15). Sistem Perdagangan Karet Rakyat [Notulensi].

Nugroho, A. D. (2021). Development Strategies of the Local Auction Market of Agricultural Product in Indonesia. Reviews in Agricultural Science, 9, 56-73.

Prastowo, A. (2012). Metode Penelitian Kualitatif dalam Perspektif Rancangan Penelitian (2 ed.). ArRuzz Media.

Purnamasari, D. (2021). Perkembangan Sosial Ekonomi Masyarakat Transmigrasi Desa Perintis di Rimbo Bujang Tahun 1975-2020. Jurnal Kronologi, 3(3), 54-64.

Raco, J. (2018). Metode Penelitian Kualitatif: Jenis, Karakteristik dan Keunggulannya. Grasindo.

Rahayu, D. P., SH, M., \& Ke, S. (2020). Metode Penelitian Hukum. Yogyakarta: Thafa Media.

Sihotang, R. (2009). Pengembangan Perkebunan Karet Rakyat Provinsi Jambi Melalui Peremajaan Tanaman. Badan Penelitian dan Pengembangan Daerah. Jambi.

Sijabat, L., Alhusni, A., \& Najib, K. (2021). Pengarub Kesadaran Partisipasi Politik Pemilib Pemula dalam Pemiliban Legislatif di Desa Pematang Sapat Kecamatan Rimbo Bujang Kabupaten Tebo Tabun 2019 [PhD Thesis]. UIN Sulthan Thaha Saifuddin Jambi.

Situmorang, S. H., Muda, I., Doli, M., \& Fadli, F. S. (2010). Analisis data untuk riset manajemen dan bisnis. USUpress.

Suharsimi, A. (2006). Prosedur Penelitian; Suatu Pendekatan Praktik. Rineka Cipta.

Sunjaya, P. (1998). Perencanaan Pengembangan Organisasi Petani di Bidang Usaba Perkebunan Karet Rakyat (Studi Kasus di UPP-PPUPKR Gunung Megang, Muara Enim Sumatera Selatan) [PhD Thesis]. Institut Pertanian Bogor.

Suyadi. (2018, Mei 23). Dinamika Perdagangan Tengkulak Karet di Desa Rimbo Mulyo [Notulensi]. 
Syuhada, S., \& Kuswanto, R. (2009). Analisis Sosial Ekonomi Penduduk Eks Transmigrasi di Desa Terantang Baru Kecamatan Batin XXIV Kabupaten Batang Hari. Jurnal Penelitian Universitas Jambi: Seri Humaniora, 11(2), 43437.

Teti, K., Maryani, M., \& Muhammad, F. (2021). Jual Beli Karet Perspektif Hukum Ekonomi Syariah (Studi Kasus di Kel. Simpang Sungai Rengas Kec. Maro Sebo Ulu Kab. Batanghari Provinsi Jambi) [PhD Thesis]. UIN Sulthan Thaha Saifuddin Jambi.

Winarni, L. (2016). Peran Tim Pendamping Program Nasional Pemberdayaan Masyarakat Mandiri Perdesaan (PNPM-MP) dalam Upaya Meningkatkan Perekonomian Kelompok Usaha Produktif di Kecamatan Colomadu Kabupaten Karanganyar. Eksplorasi, 27(2).

Yulmardi, Y. (2019). Transmigrasi di Provinsi Jambi (Kesejabteran dan Sebaran Permukiman Generasi Kedua Transmigran). CV. Pena Persada.

Yusanto, Y. (2020). Ragam Pendekatan Penelitian Kualitatif. Journal of Scientific Communication (Jsc), 1(1). 